\title{
The MaIn Risk Factors Leading To COSt OVERRUn IN Delivery Of Czech Public Building Projects
}

\author{
Jakub Stuchlík*1 \\ ${ }^{1}$ Czech Technical University in Prague, Faculty of Civil Engineering, Thakurova 7, Prague 6, 166 29, \\ Czech Republic, stuchlik.js@gmail.com
}

\begin{abstract}
Non-compliance with a construction budget threatens the development and success of building projects and reduces investor's profit. The biggest cost overruns of building projects occur in developing countries, however, construction budget overruns are common problem of many building projects all around the World and have become an industry-wide status quo. It's important to understand the root of the general problem, especially if a project budget is curtailed or in the public gaze, as in a case of public buildings. Based on the literature review, this paper discusses the main risk factors leading to cost overruns and delay of public building projects in the Czech Republic and compares the local situation with that in the World. The analysis showed that in most cases, the main factors that have major impact on project's budget overrun are those related to an inaccurate project management prior the start of a building process, such as inaccurate estimates of project's budget and timelines, serious errors in design plans, administration errors or poor site management. Adopting an appropriate precaution during a pre-construction phase, such as better communication between architects, contractors, owners and site managers or using specific construction software, can enable execution of complex projects with greater control and limit the project's cost overruns in the future.
\end{abstract}

\section{Keywords}

Public construction project, cost overrun, building budget

\section{JEL Classification}

H57 Publics Economics (Procurement)

C55 Large Data Sets: Modeling and Analysis

DOI: https://doi.org/10.14311/bit.2018.02.02

Editorial information: journal Business \& IT, ISSN 2570-7434, CreativeCommons license (c) (i) published by CTU in Prague, 2018, http://bit.fsv.cvut.cz/ 


\section{Basic information}

The construction industry has become one of the leading industries not only in the Czech Republic, but also in the World [1]. It plays a crucial role in an economic prosperity of the Czech Republic. In recent years, we have witnessed the positive development of the global economy. Within the Czech Republic, there is an increase in the overall public procurement market. In 2017, compared with 2016, the public procurement market grew significantly by 75 billion CZK to 559 billion CZK. Based on the forecasts, we expect the continuing trend in the volume of public procurement contracts in the coming years [2]. As a substantial part of public investment is spent through public procurement, a slight financial or time exceeding of the public contract will cause a considerable loss in the public budget.

It is a fact that very few of the major public building projects are completed within the project sponsors' originally estimated budget and time frame. Even relatively small cost overruns can cause disruption when a project is part of a wider program of expenditure, such as projects, supported by European Union (EU) funds and can an affect the whole state economy [3]. Therefore, identifying and reducing potential threats that could result in project budget overruns at the beginning of the project, i.e. at the planning stage, can significantly reduce the risk of exceeding the planned budget for the construction. It is necessary that the $3 \mathrm{E}$ principles of are respected when managing the funds for project implementation, i.e. the economy, efficiency and effectiveness of the project. The sponsor should focus most on the $3 \mathrm{E}$ principles during the planning and preparation phase of the public contract [4].

Project cost and time overruns may be cause by various factors that depends on a type and a complexity of the actual project and existence of an extreme diversity of conditions under which project is implemented in practice. Due to these variations, the construction process cannot become fully formulated, implementing constant variables, and controlled at all stages. Moreover, the success of the project depends on the area where the project is being carried out. Each country of the World has its own specificities, such as different rules and regulations or building practices that influence the outcome of local building projects. Therefore, it is difficult to compare the project overruns between the single countries as such. However, it is possible to observe some general problems in the public procurement process in foreign countries and compare them to the situation in the Czech Republic. Nevertheless, a nationwide survey of the main causes of public project overruns seems to be more relevant, as the one presented in this paper.

In this paper the most common causes of time and budget overruns of public projects in the Czech Republic were identified using a sample of 190 public projects implemented between the years 2008 and 2018, and the results were compared to those found by a review of local and foreign literature.

\section{Literature review}

The professional literature on public project cost and time overruns is limited mostly to a national study, presenting many factors leading to project cost overruns. The results of some selected nationwide analyses, related to the current topic, are reviewed in the following text.

In general, the project is considered as successful, when it fulfills the three main criteria: being 1) completed on time, 2) finished within budget, and 3) consistent with the specifications. Based on this concept, a delayed or overpriced project is an unsuccessful project $[5,6]$. The recent analysis of public construction projects in the United States, showed that the most important causes of project delay, defined as an extension of time that is decided for the substantial completion of a construction project, were change orders, time-consuming decision making by the owner, and design errors [7]. The author of the study offered solutions that could prevent the project delay: 1) an establishing the client's needs 
clearly and collaboration among the parties throughout the project through constant meetings to avoid change orders; 2 ) hiring designers with adequate experience, allowing sufficient time and resources to complete the design and getting peer reviews of the design by experienced reviewers to avoid poor project design; and 3) improved communication among parties through constant meetings [7]. A combination of these precautions could lead to a success of the public project.

Public project cost overruns are a global phenomenon, for which it is typical that the size of cost overruns varies with geographical location of the project. A recent comprehensive study of construction projects in different countries has identified the main potential causes of construction project's cost overrun as frequent design change, contractors' financing, payment delay for completed work, lack of contractor experience, poor cost estimation, poor tendering documentation, and poor material management [8]. According to study, frequent design change during construction phase was found to cause cost overrun in different developing countries such as Vietnam, Indonesia, and Nigeria as well as developer countries such as Korea. Financial problems of contractors during construction phase were found to be another major problem for project progression on time and on budget, especially in countries such as Nigeria, Ghana, and Vietnam. Payment delay was found to occur more often in government funded projects, because of a typically slow payment procedure. A lack of contractor experience was one of the main causes of cost overrun in different developed countries such as Indonesia and Ghana. Poor cost estimation was another issue of many public projects, as it was too optimistic. Poor tendering documents were identified as causes of cost overrun in almost $80 \%$ of studied countries. And finally, material price fluctuation and poor material management have been recognized as one of the main causes of cost overrun in $88 \%$ of cases, being a major issue in countries such as Nigeria, Indonesia, Vietnam, Ghana, and Saudi Arabia [8]. Some solution to these problems has been proposed by authors, such as effective communication between a project's internal and external stakeholders and embedding of an effective resources (human, technical and material) management system within construction projects.

A building of the infrastructure in the Europe is a key investment target of European Commission. A Germany is considered as a target of these plans, as it as Europe's largest economy. Naturally, the country also faces the problem of public project overruns and delays. The scale of recent failures in project delivery in Germany and Europe is alarming and needs to be studied more closely by policymakers and academics. A recent study of large infrastructure projects in Germany from 1962 to 2015 presented factors such as poor project governance, early planning mistakes, inappropriate risk management and unforeseen technological challenges that influence delivery of public projects [9]. The authors of the comprehensive analysis state that the mechanisms and tools to set up a project organization exist and need not be invented but only need to be applied regularly. The expert commission, staffed with 36 experienced project managers, architects, lawyers, consultants, scholars, civil servants, and other practitioner, installed by the German government in April 2013, gave several recommendations on how to improve project delivery: the finalization of planning before project start; clear, professional project governance and risk management; cooperative, transparent, and participatory planning procedures including the private side and the public; increased, professionalized use of Building Information Modeling (BIM) software tools to plan projects; paying considerably more attention to risk technical and financial risk assessment during project's design and development phases; handling legal issues between the public and private side outside of court. As the political, social, and economic systems of the most Western countries are like the German system, the abovementioned recommendations are applicable for public projects in those countries as well [9].

In Slovakia or Czech Republic, public authorities overwhelmingly prefer the lowest bid price of the public construction auctions, even though Directive 2014/24/EU on public procurement supports multicriteria evaluation of bids [10]. When using the lowest bid price as an evaluation criterion, a public contract may indeed be tendered with the lowest bid price, but not necessarily the best offer in terms 
of supplied quality [11]. Public projects are often complex and may require experts and specific technologies. A complexity of public project, together with large project size and uniqueness, favor another problem, the corruption, which is a global problem [12]. According to Transparency International, a corruption can add as much as 50 per cent to a project's costs [13]. Despite the topic of corruption is highly controversial, it is necessary to bring it to light and look for proper solutions.

The major causes of time and budget overruns of public projects in the Czech Republic are analyzed in following paragraphs.

\section{Research objective}

The aim of this article was to map out the main factors leading to time and budget overruns of public building projects in the Czech Republic and then to compare these causes with foreign countries. To achieve this goal, the authors created a database of building objects that included 190 random objects (samples). The second aim of the article was to compare the causes of the cost overruns between the Czech Republic and other countries.

\section{Research method}

For the needs of the analysis of project cost overruns in the Czechia, we analyzed a sample of 190 completed construction public objects, whose financial value ranged from 220 thousand CZK to 38 billion CZK. The objects were implemented between the years 2008 and 2018. Primary data were obtained from publicly available sources, such as the Publication Subsystem of the Public Procurement and Concession Portal of the Czech Republic, the official board of the relevant city in the Czech Republic, established economic journals devoted to this issue, such as a magazine the Construction, information portal stavebnictvi3000.cz, Czech weekly Ekonom, daily Hospodářské noviny, the pages of the Ministry of Industry and Trade, the Czech Statistical Office, databases of impacted scientific journals and other professional literature.

The 190 projects included in the study were:

1) transport structures - roads, motorways, bridges, tunnels, parking areas, bus stations, modernization of tram rails and railways or cycle routes, etc.

2) water management structures - revitalization of ponds and river beds, building and modernization of sewage treatment plant, sewerage systems, building of flood control system

3) technological structures - waste incinerator, boiler houses, power stations, substations, production halls or chemical industry buildings.

4) other ground structures - building or reconstruction of swimming pools, hospitals, nurseries, schools, kindergartens, gymnasiums, sports halls, playgrounds, stadiums, theaters, cinemas, churches, exhibition grounds, residential houses, etc.

The deadline and budget are exceeded in $86 \%$ of large construction projects (megaprojects), i.e. buildings worth 1 billion USD (approx. 24.210 billion CZK) [14]. In the Czech Republic, the public building projects rarely cost billions of CZK. Such megaproject was included in our study, i.e. Blanka tunnel complex, which final cost reached approximately 43 billion CZK (or 37 billion, when a link to Strahov tunnel is excluded). The original estimated cost of the Blanka Tunnel was approximately 23 billion of CZK [15]. Other important samples in terms of the financial demands of the construction, included to this study, were: waste incinerator ZEVO in village Chotíkov u Plzně, multifunctional KV arena in Karlovy Vary city, the extension of the metro line " $A$ " in Prague, I/38 Road - bypass of Kolín town, or judicial area in Brno city. 


\section{Results}

Based on the analysis of samples of public construction projects in the Czech Republic, it was found that approximately 6 construction projects out of ten did not comply with the "3E" principle - Figure 1.

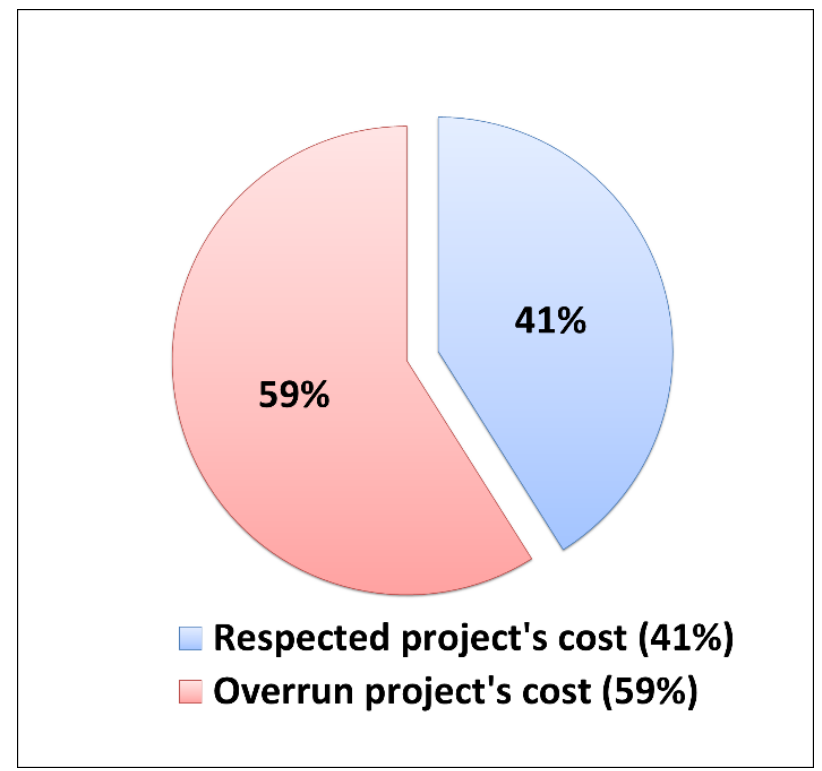

Figure 1: Compliance with the budget for 190 public building projects in Czechia (Source: author)

Of the total sample of 190 projects (implemented in the period 2008 to 2018), in $59 \%$ of them a misconduct was found, which led to project cost overrun, as summarized in Figure 2 . The main reasons for budget overrun were: changes and errors in design documents (32\%), inadequate geological research (14\%), complications or changes in building technology (12\%), climate changes $(9 \%)$, errors in project budget (6\%), failure to meet the deadline by subcontractors, archeological research (4\%), unprofessional project management (4\%).

\begin{tabular}{|c|c|}
\hline 1\%1\%1\%1\%1\%1\% & 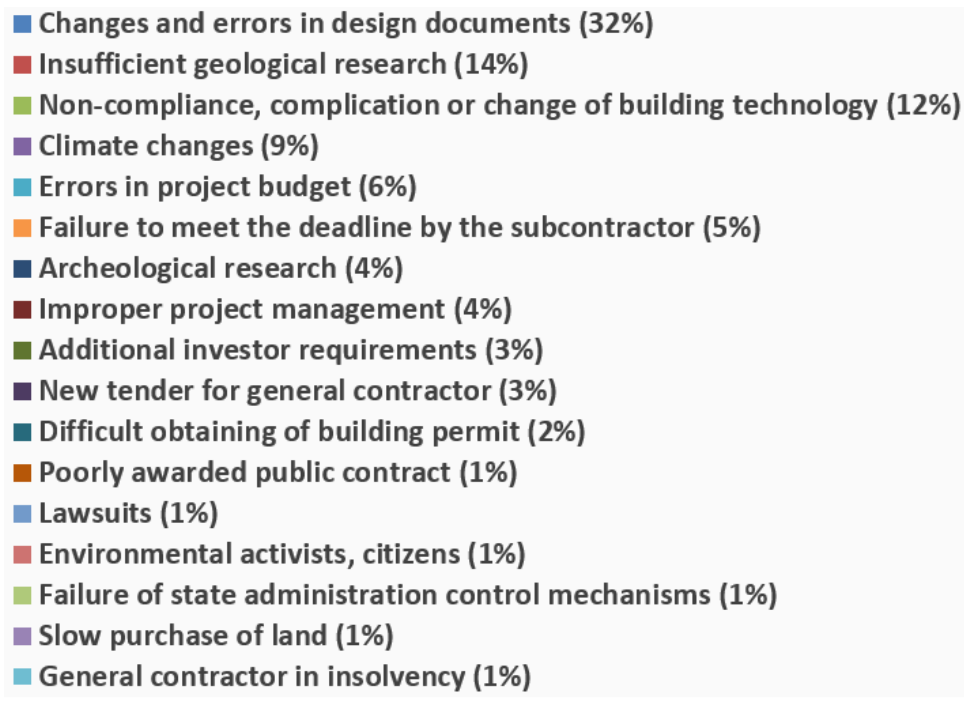 \\
\hline
\end{tabular}

Figure 2: Main reasons for the failure to meet the budget for 190 projects (Source: author) 
The identified reasons for budget failure in the analysis are in accordance with the reasons for noncompliance with the budget for foreign projects. The most common factor of project overrun were changes and errors in design documents, found throughout the spectrum of projects, such as transport structures, e.g. bypass of Kolín town, modernization of the Veselí nad Lužnicí - Soběslav line, etc. or other ground structures, such as construction work and project work on primary school Milovice Mladá or completion of the roof of the ice rink in Čáslav town.

In addition to the reasons mentioned above, another causes of public project budget overrun often occurs, such as excessive ambitions of politicians; interests of lobbyists; failure of the investor to plan and inspect the contractors during construction; the method of awarding the tender (applies to the Czech Republic); lack of involved specialists on the part of the investor [14].

\section{Conclusion}

The analysis of a sample consisted of 190 public construction contracts executed between 2008 and 2018 showed that a total of 59\% of the projects were overpriced, for various reasons.

Some of the world studies of the finished public projects describe the inaccurate project management prior the start of a building process as the main factor that have major impact on project's budget overrun. This includes inaccurate estimates of project's budget and timelines and serious errors in design plans or administration errors and failure of control mechanisms. Sometimes essential milestones are forgotten for the final successful completion of work, such as bad estimation of geological conditions, use of bad construction materials, or neglection of security measures. Sometimes there are deficiencies in the level of ensuring enough qualified experts who are able and willing to participate in the project and guarantee their professional profile for the high quality and credible outcome of the project.

Various investigations of the efficiency and transparency of the public procurement system in the Czech Republic have been done by control organs to report major problems in this filed. The Czech legislation concerning public procurement is regularly harmonized with respect to EU legislation to ensure transparency, proportionality, equality and non-discrimination, including of foreign suppliers based in EU or non-EU states [16]. The public procurement system plays an above average role in the Czech economy and is regulated primarily by the Act. No. 134/2016 Coll., on Public Procurement, which came into effect on October 1, 2016. The National Audit Office of the Czech Republic reported in its 2017 annual report that the public procurement without open economic competition, either by direct purchase or by negotiated procedure without publication, is one of the most serious problems of public procurement. These non-transparent procedures of some state institutions restrict the competitive environment and do not guarantee achievement of economic profitability. The National Audit Office has also highlighted further persistent misconduct and non - compliance with the rules of public procurement procedure, whether it was a non-creation of a sufficiently competitive environment in the tender procedure, or the purposeful division of the subject of the public contract into more separate orders so that they could be subsequently tendered in a mode of subthreshold contracts or small contracts. In general, enough level of competition is a prerequisite for efficient functioning of public procurement market and enough bids can achieve prices favorable for contracting authority [17]. Nowadays, the contracting entities must execute the proceedings under the Act electronically in full extent. This could improve the transparency of a whole public procurement process, which remains the major problem of Czech state.

A study of European Commission on administrative capacity in the field of public procurement in the Czech Republic (and other member states) published some recommendations for improvement of a quality of public procurement in the country. To simplify the public procurement, process the commission advised to publish clearer and more practical guidance materials for contracting 
authorities to allow them to more easily and confidently navigate the procurement process or provide ad-hoc support to contracting authorities such as telephone hotline or an online helpdesk. The state should define stricter rules for additional works and amendments to contracts and set up channels for bidding companies to anonymously report suspicious practices. Moreover, the state should increase sanctions for violations of procurement rules to have a deterrent effect [18].

Transparency International - Czech Republic (TI) is a non-governmental non-profit organization whose mission it is to map the state of corruption in the Czech Republic and to actively contribute to its reduction. In their The TI reports another problems of public procurement, often criticized by the European Union, such as insufficient or too narrow definition of the subject of a public contract; purposeful division of the subject of a public contract in order to avoid law enforcement regime; insufficient competitive environment during the tender procedure; breach of the prohibition discrimination or of the principle of equal treatment, in particular the occurrence of "tailored" contracts; discriminatory setting of qualification prerequisites, non - exclusion of the applicant at nonfulfillment of qualification prerequisites and subsequent conclusion of the contract with this applicant [19]. The TI sees a major problem in procurement of small orders, which are among the most frequently awarded public contracts and which are frequently full of errors. Small orders are not subject to the supervisory powers of the Office for the Protection of Competition. Since 2018, the creation of a (nonpublic) record of actual business owners, led by the relevant registry courts, has simplified the process of demonstrating the ownership structure, as the above information is nowadays required by the contracting authority to identify them and to include them in the tender dossier. The contracting authority now must exclude non-transparently controlled selected contractors from the procurement process. The $\mathrm{TI}$ recommends to strengthen the transparency of the procurement process, including more rigorous control and more effective enforcement of fulfillment of existing legal obligations; emphasis on data completeness and openness for use by the general public; extending mandatory formal procedures and increasing transparency especially in the case of small-scale public contracts; full computerization of public procurement with an emphasis on a user-friendly environment, more consistent integration and interoperability of data from existing systems or emphasis on further increasing the professional qualifications of staff involved in public procurement [19].

In this study, by analyzing the protraction of public construction projects, we have gained information, how many percent of projects are overpriced and the main reason of the budget overruns. The described information could be used in the future to establish a methodology that would help the official authorities to better manage the public construction projects in its all phases. In the future, the study could be enriched by information based on the survey, send to the participants included in the process of preparation and execution of the public construction project, which could provide an useful information regarding project budget, and possible factors that have major influence on the success of the project. Nevertheless, following the recommendations of the European Commission, The National Audit Office or agencies such as Transparency International and adopting an appropriate precaution during a pre-construction phase, such as better communication between architects, contractors, owners and site managers or using specific construction software, can enable execution of complex projects with greater control and limit the project's cost overruns in the future.

\section{References}

[1] Lange, J. E., \& Mills, D. Q. (Eds.). (1979). The construction industry: Balance wheel of the economy. Free press.

[2] Ministerstvo pro místní rozvoj. Výroční zpráva o stavu veřejných zakázek v České republice za rok 2017. http://www.portal-vz.cz/. Available online at: 
http://www.portal-vz.cz/getmedia/d5527fdb-5d70-4573-977a-04da3ba5a582/Vyrocni-zprava-o-trhuverejnych-zakazek-v-Ceske-Republice-za-rok-2017_schvalena-vladou.pdf (accessed 16 Dec 2018)

[3] Understanding and Monitoring the Cost-Determining Factors of Infrastructure Projects. A User's Guide. Available online at:

https://ec.europa.eu/regional_policy/sources/docgener/evaluation/pdf/5_full_en.pdf (accessed 28 Dec 2018)

[4] Šubrtová, J. Způsobilé výdaje v kontextu pravidel 3E. https://www.dotaceeu.cz/. Available online at: https://www.dotaceeu.cz/getmedia/864b7323-e271-4326-8b52-ec184b585039/prezentace_PRINCIP3E_864b7323-e271-4326-8b52-ec184b585039.pdf (accessed 16 Dec 2018)

[5] SCHNEIDEROVÁ HERALOVÁ, Renáta, L KREMLOVÁ a A KADLČÁKOVÁ. Kalkulace a nabídky 1. 1. vyd. Praha: ČVUT, 2006. ISBN 978-80-01-03532-0.

[6] Frimpong, Y., Oluwoye, J., \& Crawford, L. (2003). Causes of delay and cost overruns in construction of groundwater projects in a developing countries; Ghana as a case study. International Journal of project management, 21(5), 321-326.

[7] Tafazzoli, M. (2017). Investigating Causes of Delay in U.S. Construction Projects. 53rd Annual ASC International Conference.

[8] Aljohani, A., Ahiaga-Dagbui, D., Moore, D. Construction Projects Cost Overrun: What Does the Literature Tell Us?, International Journal of Innovation, Management and Technology vol. 8, no. 2, pp. 137-143, 2017.

[9] Kostka, G., \& Fiedler, J. (Eds.). (2016). Large infrastructure projects in Germany: Between ambition and realities. London, England: Springer

[10] Hanák, T., Serrat, C. Analysis of Construction Auctions Data in Slovak Public Procurement. Advances in Civil Engineering, vol. 2018, Article ID 9036340, 13 pages, 2018.

[11] Ochrana, F.; Hrnčírová, K. 2015. Does the lowest bid price eva-luation criterion make for a more efficient public procurement selection criterion? (Case of the Czech Republic), NISPAcee Journal of Public Administration and Policy 8(1): 41-59.

[12] Locatelli, G., Mariani, G. et al. Corruption in public projects and megaprojects: there is an elephant in the room! Int. J. Proj. Manag., 35 (3) (2017), pp. 252-268.

[13] Transparency International. PUBLIC PROCUREMENT. Available online at: https://www.transparency.org/topic/detail/public_procurement (assessed 20 Dec 2018).

[14] B. Flyvbjerg, M. Holm, S. Buhl, Understanding costs in public works projects: error or lie?, Journal of the American Planning Association 68 (3) (2002).

[15] ČTK. Šéf Metrostavu: Blanka je Bentley mezi tunely. Není předražená, jen zbytečně drahá. (2015) Available online on: https://zpravy.aktualne.cz/regiony/praha/sef-metrostavu-blanka-je-bentley-mezitunely-neni-predrazena/r 970b081a5a0911e58c710025900fea04/ (accessed 20 Dec 2018).

[16] International Comparative Legal Guides. Public procurement 2018 I Czech Republic. (2018) Available online at: https://iclg.com/practice-areas/public-procurement-laws-and-regulations/czech-republic (Accessed 21 Dec 2018).

[17] Národní kontrolní úřad. Výroční zpráva 2017. (2018). Available online at: https://www.nku.cz/assets/publikace-a-dokumenty/vyrocni-zprava/vyrocni-zprava-nku-2017.pdf (accessed 21 Dec 2018).

[18] European Comission. Public procurement - Study on administrative capacity in the EU Czech Republic Country Profile. Available online at: https://ec.europa.eu/regional_policy/en/policy/how/improving-investment/publicprocurement/study/\#3 (accessed 22 Dec 2018).

[19] Transparency International - Česká republika. Rizika korupce a podvodu ve veřejných zakázkach. (2018) Available online at: https://www.transparency.cz/wp-content/uploads/Srovn\%C3\%A1vac\%C3\%ADstudie-OLAF-Rizika-korupce-a-podvodu-ve-ve\%C5\%99ejn\%C3\%BDch-zak\%C3\%A1zk\%C3\%A1ch.pdf (Accessed on 22 Dec 2018). 